\title{
Bridging the gap to those who lack: intercultural education in the light of modernity and the shadow of coloniality
}

Robert Aman

\section{Linköping University Post Print}

\section{Tweet}

N.B.: When citing this work, cite the original article.

This is an electronic version of an article published in:

Robert Aman, Bridging the gap to those who lack: intercultural education in the light of modernity and the shadow of coloniality, 2013, Pedagogy, Culture \& Society.

Pedagogy, Culture \& Society is available online at informaworldTM:

http://dx.doi.org/10.1080/14681366.2012.759139

Copyright: Taylor \& Francis (Routledge)

http://www.routledge.com/

Postprint available at: Linköping University Electronic Press

http://urn.kb.se/resolve?urn=urn:nbn:se:liu:diva-87171 


\title{
Bridging the Gap to Those Who Lack: Intercultural Education in the Light of Modernity and the Shadow of Coloniality
}

\author{
Robert Aman \\ Linköping University
}

\begin{abstract}
Academic courses on interculturality have become a rapidly growing discipline in the West, where supranational bodies such as the EU and UNESCO promote intercultural education as a path towards improved global cultural relations. Through interviews with students who completed a university course on interculturality, this essay investigates the tenets of interculturality and problematises whether this discourse merely reproduces a classificatory logic embedded in modernity that insists on differences among cultures. The argument put forward is that in the analysed context, interculturality tends to reproduce the very colonial ideas that it seeks to oppose. In doing so, interculturality reinforces the collective 'we' as the location of modernity by deciding who is culturally different and who is in a position that must be bridged to the mainstream by engaging in intercultural dialogue.
\end{abstract}

Keywords: coloniality, modernity, interculturality, interculturalism, intercultural education, postcolonialism

\section{Introduction}

In her novel, The Inheritance of Loss, Kiran Desai (2005) addresses the painful consequences of globalisation: social and cultural displacement, whether in exile or within the frontiers of the nation-state itself. Despite the multiple, geographically distinct settings of the plot, a unifying trait of the central characters is that none of them are at 'home' in the Himalayan India where they reside - or once resided, as some seek new lives in the front yards of the former colonisers - in the wake of globalisation. Through local actualities, Desai seeks to capture how globalisation implies a tension between sameness and difference, between the universal and the particular and within the simultaneity of the global and the local. Specifically, she examines social relationships that transcend - or that result in the dissolution of - cultural, national or regional boundaries. By describing (and mocking) the seedy remains of the colonial endeavour, Desai presents a broader interpretation of globalisation as a direct consequence, like modernity, of a European expansion built on capitalist society and Western culture. Thus, globalisation is related to the broader Western discourse on industrial and capitalist progress, which is an ideology on the development of society and transition to modernity. That is, the discourse concerns itself with progress not only in economic terms but also for the inhabitants of the communities in which modernity is achieved.

On a broader note, leaving Desai for now, the rhetoric of globalisation is supported by the continually evolving post-enlightenment discourse of progress and its promise of a leaner, more efficient economy that will benefit all nations, even though in the short run, some sacrifices must be made (in terms of displaced traditions, families and communities) for the sake of development and modernisation (Banerjee and Linstead 2001). Despite allusions in everyday speech to life in a 'global' village, competition in a 'global' marketplace and membership in a 'global' economy, these concepts are paired with classifications such as 'ethnic community', 'informal economy' or 'minority groupings', which interlock 
globalisation and multiculturalism as mutually reinforcing discourses in which the latter emerges as a concept employed to handle the descriptive consequences of the former (Banerjee and Linstead 2001; Hardt and Negri 2001).

Globalisation is subsequently theorised beyond its economic aspects and is emphasised equally as a social, cultural and political process in which subjectivities and social relations are produced and illustrated by, for instance, the European Union's communique that 'cultural diversification has gained momentum' because the continent has attracted migrants from across the world as an effect of globalisation (EC 2007a, 3-7). In Europe, the consequences of migration movements are being addressed by both the national and supranational bodies through the implementation of policies on interculturality. This point is illustrated by, among others, the growing body of literature on interculturality (cf. Brantefors 1999; Camilleri 1992; Santos Rego and Nieto 2000) and the number of EU projects in support of intercultural interventions (cf. EC 2007a; 2007b) that accommodate the articulated cultural and religious pluralism. With interculturality as a foundation that allows cultures around the world to come into tolerant contact with each other in a type of immense cultural pluralism, the discourse on interculturality has not only influenced intercultural policies per se but has also led various supranational bodies, such as UNESCO, the EU and the Council of Europe, to frame interculturality within the standard context of education as a means to safeguarding liberty, justice and peace (cf. CE 2008). The premise is that intercultural education provides all learners with cultural knowledge, attitudes and skills that enable them to contribute to respect, understanding and solidarity among individuals, ethnic, social, cultural and religious groups and nations' (UNESCO 2006, 37). Given that UNESCO's mission will at least partly influence educational policies worldwide to ensure an intercultural approach, the EU has correspondingly incorporated interculturality into its educational program for 'Lifelong Learning' (EC 2001) and now advocates for interculturality to be included in the education curricula at all levels in its member states (EC 2007a). As a consequence of these interventions, academic courses on the subject in the West have grown rapidly (cf. Dahlén 1997; Dewey 2008), and interculturality has become a prominent educational theme at the vast majority of the universities in the context of this case study: Sweden. ${ }^{1}$

Given the substantial attention directed towards interculturality, my objective with this essay is to scrutinise how the discourse on interculturality unfolds in the sphere of higher education by analysing how it is produced in a local context (i.e., a university course). Interculturality refers to the interactions among cultures and the importance of fostering and guiding such relations. Educational courses on interculturality have become the primary medium used to meet governing bodies' objectives of equipping their subjects with the desired competences that will enable them to participate in a culturally diverse world. Bearing this point in mind, this essay uses empirical material composed of fourteen semi-structured interviews with students who have successfully completed an academic course on interculturality $^{2}(30 \text { ECTS })^{3}$ at one of Sweden's major universities to develop a critical interrogation of the core components, meanings and definitions of the discourse on interculturality. Given that interculturality presupposes cultural diversity, I will illustrate the ambivalent nature of the delineation of cultural boundaries and the risk of appropriating

\footnotetext{
${ }^{1}$ Through the academic year of 2010-2011, the following Swedish universities gave at least one course on interculturality: Dalarna University, Göteborg University, Jönköping University, Karlstad University, Kristianstad University, Linköping University, Linnaeus University, Lund University, Malmö University, Mid Sweden University, Södertörn University, Umeå University, University West and Uppsala University.

2 The course concerned here collaborates with indigenous movements in Latin America to empower those organizations.

${ }^{3}$ European Credit Transfer System. 30 ECTS equals one semester of full-time studies.
} 
coloniality inherent in the quest to legitimise intercultural interventions in the name of modernity and social cohesion. To date, not only this task in particular but also the task of critically studying the discourse on interculturality in general has failed to attract significant interest among researchers and has therefore been relatively neglected (James 1999). Chaudhuri (2002) and Kymlicka (2003) argue that one reason for this neglect is that researchers interested in this field are often themselves engaged as practitioners and therefore implicitly assume the value of interculturality. Consequently, researchers are reluctant to propose any critiques of this subject. Thus, intercultural theory is often developed alongside practice by the practitioners themselves in an attempt to justify, elucidate and legitimise its conformity (Chaudhuri 2002).

As discussed in the previous section, the general pedagogical orientation toward the global multiculturalism of today is considered to be intercultural education (Sutton, 2005), replacing, albeit on a conceptual level, previous educational strategies to knit cultural scraps and patches into a social texture. Perhaps of further importance then is whether an actual paradigm shift (rather than a mere change of conceptual authority) occurs with the pretension of articulating the 'true' knowledge of the phenomena at hand. According to Hardt and Negri (2003), the answer can be found in the sine qua non of late capitalism for new domains and niches. Areas focused on cultural diversity competencies (e.g., intercultural education, diversity management, multicultural counselling and cross-cultural communication) reflect the ability of advanced liberal societies to cultivate flexible and reflexive subjects who are able to adapt to new situations and deal with exposure to the non-familiar. These ideal citizens can keep up with the times in that they will view diversity as a positive and desirable phenomenon. Without negating the existence of an opposite ideal among the ethno-national parties in different areas of Europe, this public discourse on diversity is visible in, for instance, the Swedish government's bill (2001/02:15) on higher education, which emphasises the benefits of 'diversity' and brings up the shifting demography of society as the main reason for reforming academic programs. Correspondingly, as all universities in Sweden are obliged to have a policy on diversity, 'diversity' has become a prestigious word, something to safeguard and endorse (cf. de los Reyes 2001).

Although rarely presented in this manner in analyses of cultural diversity, the historical backdrop suggests that the modern world is the product of global flows that started in the late fifteenth century and that continue to affect humanity. In this sense, globalisation continues this process of cultural production and domination, in which Western interests are projected as the world's interests and thus become naturalised in the rest of the globe (Trouillot 2003). Multiculturalism gained prominence together with the politics of globalisation. Based on the recognition, inclusion and incorporation of cultural diversity, multiculturalism has also been criticised for maintaining the existing systems of capitalist economies, colonial differences and Eurocentricity rather than transforming them (Mignolo 2005). Conversely, interculturality arose among other places as a social and political project among the indigenous movements in Latin America ${ }^{4}$ as a critique of multicultural policies and their recognition of minorities within the structures of the neoliberal system. The proponents of the movement argue that interculturality requires a decolonisation of the vertical relations that emerged under colonialism and thus the creation of another social order distinct from Western subjectivity as well as the perception of epistemology as singular. This argument is a radical claim for 'epistemic rights' rather than the 'cultural rights' celebrated by the states in Latin America,

\footnotetext{
${ }^{4}$ A few of these organizations are Kawsay, Confederación de Nacionalidades Indígenas del Ecuador, Concejo Regional Indígena del Cauca and Federación Nacional de Organizaciones Campesinas, Indígenas y Negras.
} 
the EU and the US. In this context, interculturality does not articulate the same logic in two different languages or from two different cultural standpoints but rather puts two different logics into collaborative conversation (Mignolo 2005). Nonetheless, the adoption, translation and institutionalisation of interculturality by the West through supranational bodies and state governments has altered its meaning to be synonymous with multiculturalism (Mignolo 2005). This change has led to interest in how interculturality unfolds within higher education in the West. I will now focus on how this analysis is conducted in an attempt to explore these questions.

\section{Strategies of otherness and the underside of modernity}

At this point, it should be noted that a unifying trait among the theories of differentiation is the presupposition of subjects as agents of cultures and thus as possible creators of cultural plurality. However, when inscribing a subject into a collective, scholars incur the risk of homogenising the subject or appropriating the strategy of otherness, which Said (1978) labelled 'Orientalism' in the context of the Middle East. To amplify, for Said any verbalisation of a radical difference, regardless of whether this difference is based on gender, race or - as in this particular scenario - culture, sets the mechanisms of otherness in place; such an act is never neutral. Additionally, it does not matter whether the differentiated culture in question is valorised positively and praised (as in the public discourse on diversity). The essential operation is that of disjunction, and once it has been accomplished, the Westerner develops what Said $(1978,7)$ refers to as a 'flexible positional superiority', which implies that Westerners may adopt a variety of possible relations to the culture at hand without ever losing their dominant position. This superiority relies on the privilege of dominant categories of thought inherited from colonialism. Through these categories, the rest of the world can be classified, represented, understood, 'improved' and 'developed'. Within this conceptual approach, the sum of these conditions and characteristics is commonly referred to as 'modernity': an ideologically constructed condition that spatially separates Europe or the West from other parts of the world.

Modernity emerged through colonialism and was formed in a dialectical relation with a non-European alterity as its contrasting image. There cannot be modernity without coloniality, claims Mignolo (2005); the two constitute each other, as coloniality demarcates the hierarchies at modernity's heart. Invoked in modernity are the teleological macronarratives of development, enlightenment and human progress, which are based on the founding concepts of Eurocentric thought. These concepts are delineated into evaluative binary structures, such as primitive/civilised, beliefs/science and traditional/modern (cf. Dussel 1993). Through this logic, the West has represented its others as existing on the same historical trajectory but further behind. We all share the same objectives, but not everyone has achieved them to the same degree; our knowledge is subject to the same justificatory procedures and schemes, but others are less developed. Modernity is thereby the entry ticket to the development and salvation invoked in Western narratives and models. That is, the rhetoric of modernity is the justification for coloniality: to be saved by modernity (Mignolo 2005). The concept of modernity inventively conceals the significance of spatiality for the production of this discourse, and as a result, most who adopt the discourse tend to embrace a universalistic perspective that negates the importance of geopolitical location for the historical grounding of knowledge, which turns the West into a universal yardstick (Maldonado-Torres 2004). Thus, in this paper, the 'West' does not entail a geographical space but is instead an expression of modernity, a product of knowledge that was built on categories and concepts rooted in Greek and Latin languages and the modern/imperial unfolding of the West. 
The nexus of modernity/coloniality as a theoretical horizon offers analytical tools for better comprehending how interculturality in the West may reproduce coloniality by appealing to modernity as a means of achieving global tolerance, as is argued to be the case with other theories of differentiation, such as multiculturalism or cosmopolitanism (cf. Mignolo 2000). According to Said (1978), the principal basis for claims of radical differences among, for instance, regions, communities or cultures is that of representation. Given that interculturality presupposes cultural diversity, any enunciators on intercultural encounters must locate themselves vis-à-vis the presupposed cultures in question. Translated into a text, this argument states that structures are built through the circulation of images, themes and linguistic expressions, all of which add up to deliberate ways of explaining interculturality and representing different cultures.

The empirical foundation of my analysis is composed of interviews conducted with students who completed a university-level course on interculturality. According to the curricula, the students are taught to apply an intercultural perspective on 'cultural encounters in a globalised world' and on the 'exchange of knowledge among cultures'. Additionally, students are taught to 'act in a concrete intercultural environment'. Thus, the students are positioned as subjects who represent the desire and idea of interculturality in the West in that their position $\mathrm{s}$ are compatible with statements on interculturality from supranational bodies such as the EU and UNESCO. This point illustrates how the interviewees' declarations are part of a larger reasoning such that the individual subjects themselves are not of interest for the study conducted. Having conducted semi-structured interviews with fourteen students, the questions posed related to their views on interculturality and how they have transposed the knowledge acquired inside the classroom to outside it. Borrowing from Said (1978), my analysis employs close textual readings of transcribed interviews, whose average duration is 43 minutes, by emphasising descriptions, rhetorical constructions, images and social circumstances rather than the correctness of the representation. The focus is not on what the interviewees 'really mean'; instead, the focal concern is the discursive production of logic and meaning and how coloniality may operate within this production. The analysis below is divided into three parts. I begin by focusing on how interculturality is discursively defined and then move on to describing the classificatory logic among different cultures that is produced by the discourse as the foundation of an intercultural encounter. I conclude with a discussion of how knowledge is mobilised among articulated cultures.

\section{Multiculturalism was yesterday, interculturality is tomorrow}

What emerges from the curriculum and literature assigned to the course is a uniform view of how interculturality requires multiculturalism. Whereas multiculturalism is presumed to describe the demographic makeup of a culturally diverse space, the inverse of which is monoculturalism, interculturality expresses the evolving relations among different groups. The students emphasise the need to start thinking interculturally and to express a sustained opposition to multiculturalism. The following is a statement by Anna:

\section{Me: What's multiculturalism?}

Anna: Something I definitely don't like.

Me: So it's not the same thing as interculturality then?

Anna: Absolutely not! It's like us versus them. I feel like it's more about establishing a fact. It only says that there are many cultures, but it does not show that there's some kind of interaction. It's a dead word. Interculturality demands perhaps more. It requires that you give a little bit more of yourself to open yourself. You don't have to do that if you conclude that we live in a country with many cultures [...] I think that it's extremely antiquated to talk about multiculturalism only as a term that describes how things are. Interculturality is a good concept that describes something more, and we have to become intercultural if we're to get away from the antagonism that exists in society. 
The students differentiate between the two terms: they argue that multiculturalism represents a static condition of society that lacks the progressive elements allegedly embedded in the egalitarianism of interculturality. Also apparent is the discomfort expressed by Anna in relation to multiculturalism. She refers to the term as stigmatising and antiquated which she argues is undesirable. She even proposes abandoning the concept. This critique of multiculturalism is shared by postcolonial theorists such as Bhabha (1994), who argue that multiculturalism has lost its intellectual legitimacy because it constitutes a colonial perspective on culture that is based on a predetermined and essential cultural identity identified through dichotomic thinking. The anxiety articulated by the students in relation to multiculturalism broadly illustrates the public discourse on diversity and how an imagined 'we' need to regard cultural pluralism as an enriching resource rather than as a problematic issue or a matter of indifference. The harsh words expressed by the interviewee may have a symbolic value that could be summarised as follows: this issue is close to my heart and is something I care deeply about.

This line of reasoning, which identifies interculturality as a means to closing the antagonistic social gaps in society, is a view that overlaps with the motives of, for instance, the EU or UNESCO to make interculturality part of their educational programs. With all of the informants speaking to the value of interculturality - including policy documents and teaching curricula - in public discourse, the students share the notion that multiculturalism is antiquated, as described by the respondent above, and that interculturality is the present and the future. In other words, the vision presented is in line with the premise of classical integration ideology, which states that societies must find a way to overcome the fundamental differences among 'diverse cultures'. However, whether the presupposed antagonism of society's social order ought to be bridged requires further scrutiny. Specifically, the conditions in which this bridging could be realised require further study. Similar to Anna, a common approach among the informants is to describe interculturality as a process and a method for interaction and exchange. Here, with Adam:

Me: Could you explain what interculturality means?

Adam: It means cultural meeting. Cultures that meet and blend, that perhaps together create a new culture. One picks the different pieces, and perhaps together, these pieces form a new kind of culture. One lets the cultures of both sides or ways of being or whatever one defines as culture to live on. It's not like one tries to shove one of them down the other. Rather, one tries to live on but together with other cultures, and then one maybe creates a new culture jointly. This is what I feel is intercultural: the meeting between cultures.

For Adam, interculturality also seems to be a strategy for bridging the gaps among cultures. Its aim is to exchange cultural features to produce something new. However, within this process, the interviewee carefully emphasises that there is no room for hierarchies. Rather, the interaction ought to be based on mutuality and symmetry. In this respect, cultures should continue to blossom independently and also interact at the same time, and different pieces should combine into a joint culture while simultaneously retaining their specific features. Several of the examples provided by the informants on the concept of interculturality relate to humans as the bearers and intermediaries of culture, in which the prefix of 'inter' characterises interactions with the people of other cultures. In one sense, the logic of the cultural meetings metaphor, which is also emphasised in the larger discourse on diversity, seems contradictory. On the one hand, the meeting values encounters among people as part of the cross-cultural dialogue, a moral investment in which we meet others, interact across cultures and learn about each other and about ourselves. On the other hand, the metaphor delineates boundaries in that it emphasises the existence of a cultural barrier that needs to be bridged, which ends up reifying differences (Dahlstedt 2009). Paradoxically, under the 
approach the students use to move away from binary opposites, a new form of dual thinking replaces the old line of thought. As in the critique of multiculturalism, this terminology presupposes the existence of fixed cultures that can be merged and thereby lead to cohesion instead of the current state of supposed antagonism. In that sense, this approach reflects the hopes of the informants and of the abovementioned governing bodies. The acknowledged desire to construct a new joint culture and the reference to 'both sides' show that this reasoning perceives cultures as homogenous, static and autonomous entities, whereas people, according to the metaphor, are representatives of a given culture - implicitly singular - that can be amalgamated into a new combination.

According to Bhabha (1994), these contradictory beliefs lie at the centre of colonial discourse. That is, these beliefs postulate that the subjects of the world share essential commonalities, but the positioning of these convictions also reveals knowledge of existing differences (the authority of interculturality) - the Other is the same yet different. In this particular case, the students' preferences for interculturality as the method for resolving social opposition issues based on cultural diversity is embedded in a desire for a radical obliteration of differences or a closing of the antagonistic gap for the sake of social cohesion. As the passages above indicate, interculturality requires interactions in which 'you give a bit more of yourself' or 'you open up yourself'. As Anna noted, the concept is argued to be 'more alive, to be forward-looking'. This bleak image of the present and the call for a solution illustrate the rhetoric of modernity as a destination to which 'we' need to arrive. Here, sameness is turned into potential (the formation of a joint culture), which, through everyone's involvement and intercultural mindsets, is gradually turned into something current (a nonantagonistic society). Thus, interculturality may be conceptualised as a relationship of power insofar as one party is seeking to fulfil the desires of all parties for the sake of society as a whole. As a result, involvement is both voluntary and peremptory. Although the intentions may be the opposite, support for interculturality may inevitably invoke aspects of the colonising tendencies that interculturality seeks to oppose. Additionally, the groups may not find the idea of togetherness compelling, or the concept of interculturality may fail to evoke a positive meaning for the subordinated groups. This scenario would contradict the notion of interculturality, as it would cause individual cultures to persist.

Several of the quotations illustrate the linguistic entrapment in statements about diversity: an inability to resist the power of language to name and classify. A group must always be abstracted or fantasised on the basis of isolated individual contacts and experiences that can never be generalised in a mode that is not offensive. Jameson (1993) notes that regardless of how proper and respectful the relations among groups are, these relations are always stereotypical in the sense that they must involve collective abstractions of other groups. Irremediably, cultural groups are always the idea of others (even when applied to oneself), whereas the observer is an individual (just as the Neoclassicists hardly perceived themselves as a culture). The decisive point then is how a culture perceived as the other is defined and the content of this culture is ascribed. By analysing this process, we can comprehend to a greater extent the discourse on interculturality that the informants are constructing as a way to resolve identified antagonism.

\section{A postcard from another epoch: refutation of time}

The interviewees continually emphasise the conditions and implications for intercultural practices and experiences with cultural disparity. The students' interests in interculturality initially appear to be marked by fascination with remote territories and personal travelogues, experiences that - as will be discussed later - serve as platforms for exploring intercultural relations. This impression is further established by the topics of their written course papers, 
such as 'Craftsmanship in Nicaragua', 'Living conditions for the indigenous people in Bolivia' and 'Perceptions of democracy in Guatemala'. One informant comments on his and other students' choices of subjects: 'I come from Halmstad and I think about how little I know about Halmstad. It's so embarrassing! I know like ten times more about Cochabamba. [Laughter.] I could write about the construction of Halmstad's football stadium, how it has affected the local population. However, then I think, what would I do that for?'

A unifying trait among all of the informants is that they have all resided, worked, studied or experienced extensive travelling in either Latin America or Africa (with the exception of two students who referred to experiences from the Middle East in a similar manner). For all of the students, these regions serve as the bases of their interests in other cultures. However, these experiences also portray the factors that distinguish a presupposed different culture (i.e., the starting point of an intercultural encounter). The purpose is not to undervalue descriptive postulations of different ways of life; rather the aim is to problematise these statements in relation to the discourse on interculturality. Likewise, this analysis demonstrates the students' economic and material privileges, which enabled them not only to travel the world in the first place but also later to enrol in the course and reflect on the selected paper topics. Here Liza refers to her volunteer work in Latin America before enrolling in the course as a source of her interest in interculturality:

Liza: Latin America has fascinated me for a long time. It's hard to say why really, but I had always wanted to go there and see that part of the world - how it is for real and so on.

Me: Did you encounter other cultures?

Liza: Absolutely! For instance, if we're talking about the rain forest, there were indigenous people there that I met actually - it was super exciting. And they lived there in this small village and one got to hear a lot about... I got to know a woman a bit who was a potter and made ceramics that she sold. It was fun because then I got to spend time with her and make ceramics and such. You get to hear a bit about her family and some history back in time, and it felt like... It's a really completely different world than our own history. It's so very different. They've had like a lot of small village wars in the rain forest. Small villages that... it's full of... I don't know how many indigenous people there are in the Amazon, but there are a lot. All these people were at war with each other. A lot of them anyway. There were wars going on from time to time, and she told me a bit and so on... I mean, it's like a fairy tale.

Apparent here is Liza's emotional attachment to Latin America and the Amazon. The quotation indicates that her positive feelings for the region were present even before she had the opportunity to make the desired visit. Driven by the desire to know 'how it is' there 'for real', she aimed to write her own textual descriptions of the location, which may or may not have been compatible with her previous image or expectations of the space. However, the quotation indicates a semiotic combination between the modernistic protagonist and an archaistic context that provides a distorted trajectory. By remarking that she experienced a site that was 'so very different' and offering fragmented anecdotes of events, habits and chores considered exotic in the modern West, she projected the space as an antithesis to the Western world with which she identifies. In this example, the informant comments on what is considered a space and people whose realities have not required attention from Westerners. The history may be dissimilar from 'ours' or a 'fairy tale', depending on the European observers' abilities to attest to its existence. Although Liza narrates a tourist's tale describing the things that caught her attention, there is another effect: the critical language of duality incorporates a spatial imagination into geopolitical thinking - centre and periphery, metropolitan city and village, Western travellers and indigenous tribes (cf. Bhabha 1994). As in the case of Said's (1978) analysis of the Orient, Liza's statement is embedded in a discursive myth of 'discoveries' of 'isolated' people resistant to time and pre-historic versions of the human being who are represented as eternal and unique. Through these myths, nonWesterners are denied their evolution and state of flux; their way of life becomes a rhetorical 
confirmation of the myth's legitimacy. Both their localities outside of the Western world and their identities as former European colonies frame the geographical context in which the informants narrate their experiences. Their people are both the very populations that the colonial policy sought to guide into civilisation and, conversely, in cases of migration to Europe, the ones labelled as the source of 'diversity' and possible carriers of cultural values that may conflict with European ones.

The scenery sketched above denotes the student body's general construction of otherness: the schematic combination of geographical distinction (Sweden/Latin American) and temporal spatiality (here-and-now/there-and-then). By the same token, and to illustrate the similarities in how the construction of otherness operates in the verbal texts of the informants, here Sophie describes her impression of residing in Kenya as an example of when she encountered another culture. Answering the same question as Liza, Sophie reflects on the issue:

Sophie: When I was there, it was more or less like going back to the 1950s. In the store, there was a clerk who weighed your vegetables when you put them in a bag, and there were a lot of people to ask if you had an inquiry, which means there were a lot of people working there. At the bus, which was privately owned, there were always two who worked - one who drove and one who collected the money. It was like this in Sweden once upon a time, but it is not anymore. By looking at what is happening here, I do not know if it is better here than what they got there. There everyone gets a job, there's no unemployment, there's no... well, there're drugs and alcoholrelated problems, but not because of the same reasons as here. Here, you come into a store, and there's no one to ask. You find nobody. Is this something to strive for? Is it better than the 1950s? To me, it is not. They see it [Europe] as some kind of mechanical marvel; for them, Europe is really special. However, I do not know.

In this quotation, Sophie articulates an evolutionary journey that separates the two spaces: Sweden and Europe on the one hand and Kenya and Africa on the other. Principally, however, the informant uses Africa as a foundation to criticise the dismal effects and social costs of post-industrialisation and modernity that she experiences in Europe. She argues that the Kenya of today resembles the Sweden of the 1950s, which she explains was a society characterised by more human interactions, care and social security. This society was far from the sterile, mechanical and contemporary climate to which she had grown accustomed. Listening to Said (1978), these statements uncover a positional superiority: the inherited power to survey and judge spaces in geo-social comparison, the ability to rise above immediacy and the ability to use the resulting knowledge to affirm the disparities between past and present, between the desirable and undesirable and between cause and consequence. Subsequently, the inability to explain the world without measurements of progress serving as society's central code designate the subject who is subsumed in a history modelled on modern Europe as the one who can make such affirmations. This point is evident in the quote, in which it is 'they' who see Europe as something 'really special' and believe it to be a modern wonder. In contrast, her positional superiority informs her that there is a downside to modernity. As a result, their way of reasoning is confirmation that they know not what we know.

The quotation, then, unveils two interlocking themes. On the one hand, the informant essentially reproduces a decisive discourse of Eurocentrism: a legitimate critique of the West can only be found within its own legacy (thou shall not go down twice to the same river), and the present projects the past as its own repetition. On the other hand, these statements point towards the asymmetrical nature of cultural encounters, in which one part is superior by possessing knowledge that the other lacks. This knowledge concerns the subject's own reality as much as knowledge about the reality of the Other (i.e., the Westerner's dominant position in relation to the invoked subject). Although not necessarily part of the students' aspirations, bracing against a cultural context also transforms it into an object against which advancement can be measured through a linear view of history. As in the case of these quotations, these 
affirmations help reinforce the image of African- or Latin American soils and inhabitants as fundamentally different from the West. In that sense, these quotations echo the words of the Brazilian author Euclides da Cunha $(1944,161)$ : 'For it was not an ocean which separated us from them but three whole centuries'.

We need to further examine the tension between the stated purpose of interculturality and the asymmetrical relationships between the counterparts that take place in its cultural encounters. The next part focuses on the discursive level of interchange between subjects engaging in praxis to bridge cultures. In other words, emphasis is on how knowledge mobilised by the students is perceived in relation to other cultures and, conversely, what is recognised as the main virtue of the presumed Other.

\section{Scientific teaching, emotional learning}

Distinguishing spaces as belonging to separate time zones would seem to be on the order of a myth, given the degree of rhetorical and representational power in which the others are constructed in light of the students' own histories, as indicated by their quotations. Repeating the conclusion of the above paragraphs recalls how such proclamations on cultural contexts may have multi-layered effects on encounters with cultural pluralism. Here, the issue at hand is brought down to the physical proximity of the social terrain - the face-to-face - by inquiring what the informants believe they can contribute in an intercultural practice. According to both course curricula and the policies of previously mentioned governing bodies, the operation of intercultural practice encompasses interaction, mutual interchange and learning, with the latter category as the primary one on which the informants focus. A continuous theme unfolding among the students is that of focusing on what they may be able to teach the Other in an intercultural dialogue. Here, this illustrated by one student, Stephen, who refers to what he considers to be his main task when in Latin America by emphasising skills he seek to transfer:

Stephen: Efficiency, the ability to do several things at the same time. Time is valuable. It is a big conflict with time. It is like that with the cultural aspects with which they clash, of course. Efficiency is one of those key aspects that one seeks to help out with time, to seize time. Otherwise, nothing happens; one does not get anywhere. [...] I think that they are perfectly capable of doing it themselves but that one can assist and help out. To be something like an assistant coach or something to them.

There is a consciousness in Stephen's description, which acknowledges that there is a risk of conflicting cultural aspects in interactions. This quotation highlights the issue of time, which, in this particular scenario, Latin Americans are argued to experience aberrantly: they do not cherish it, they do not value it. This quote demonstrates an inherent contradiction that characterises the ambivalence embedded in the informants' statements on interculturality. In one sense, the subtle rhetoric suggests that we are all equals, an idea anchored in the agenda of universal human rights, whose ideals are considered the cornerstones of interculturality by both supranational bodies (cf. UNESCO 2006) and the students ('It's not like one tries to shove one of them down the other; rather, one tries to live on but together'). In another sense, however, it is the alleged task of Westerners to spread the blessings of modernity to help others (i.e., others need to be taught efficiency). On the one hand, this perspective proposes that they are capable of acquiring a Western perception of time and productivity on their own (sameness: we are equals); on the other, it undermines their ability by insisting on the need to supervise them and to assist them because they cannot do it on their own (difference: we are not equals).

There are two larger interwoven issues at stake here. Firstly, Stephen's account expresses the idea of a specific level to which the invoked Latin Americans ought to ascend 
by becoming efficient. This notion recalls the depiction of Westerners as the subjects of history and thereby the possessors of knowledge on how others can reach their level. By the same token, Joseph Conrad ([1902]1973, 12), in Heart of Darkness, equips his embodiment of the colonial project, Marlow, with similar lingo: 'What saves us is efficiency - the devotion to efficiency'. Governed by economic factors and embedded in a capitalistic logic of increased production as central code (i.e., time is money), this particular idea of efficiency illustrates on a larger scale that the discourse on interculturality reproduced by the student body is situated within a Western framework and its ways of life. This framework assents to capitalistic development rather than critique the system itself, which was the initial purpose of interculturality. The use of metaphors defining time as something that can be 'saved' or 'valued' further establishes this reasoning. Secondly, the logic manifested in Stephen's account has historical implications related to the doctrine of the colonial regime that legitimised its presence and subjugation by applying the same vernacular as the student body: economic and technical development and the notion of a colonised subject as a locality to be absorbed by a global economy. This logic dictates the necessity of enabling the colonised subject to enter modernity. To become is to become different; to become modern is to become Western. It is important to note that the discourse produced here is radically different from that of biological justifications (i.e., race, gender, skin tone), as it addresses a difference that is relative rather than absolute. We are all part of the same historical register; what separates us are the stages or levels that we are on, and therefore, it is the humanistic duty of those who are elevated to rescue the less privileged from the shackles of underdevelopment (Azar 1998).

A consequence of the discourse above is the legitimisation of hierarchies and the devaluation of the perceived Other's ways of being and doing. This consequence is often the result of a benevolent idiom or, as Mignolo (2005) notes, the reproduction of coloniality through appeals to modernity. We instruct 'them' out of concern for 'them' for 'their' sake; otherwise, 'they' do not develop ('nothing happens, one does not get anywhere'). Indirectly, we fear that they will not become like us. With this point in mind, what remains to be uncovered is what the student body considers to be the contribution of its counterpart in an intercultural practice. John's perspective on Bolivia gives us an example of this perceived contribution:

John: We grow up, in some way, to be individualists more than one raised in Bolivia and South America. There's another way of thinking about it [there]. [...] It becomes, in some way, more concrete there, where poverty and misery come much closer to you, which also makes you think of what's important in life. In fact, everyone ought to do a trip like this at some point. Meet those poor children in the street who're three years old and play guitar to scramble some money. Somewhere, one needs maybe to torture oneself to understand what is important. It's easy just to shut your eyes to this. We're not exposed to it except for on TV, and it's rather simple to just change the channel. Over there, it's not like you can just cross the street the whole time because they're there too. So I think that it's good, even though it's hard to see it. Their exchange to us is more on the human side, and ours relies more on concrete knowledge.

What emerges once again is the divide between those with whom the informants identify (Europeans) and their dialectical Other, who consist of Bolivians and other Latin Americans. In line with the previous discussion, the logic manifested at the end of the statement includes a colonial mentality: the scenery of savoir faire, regarded as original and innovative in Europe, is now to be repeatedly consumed in other parts of the world, which simultaneously contributes to the illusion that there is little to no production of any significant knowledge outside the realm of the West. This illusion points to a departure from the discourses of equality and dismantled hierarchies that surround interculturality. The chosen words encompass the perception of 'concrete knowledge' as something that can be vertically transferred. Similar to a gift, 'concrete knowledge' is an object that does not really belong to its receiver, its content being alien in its transferred locality. On a larger scale, the quotations 
illustrate a structural relationship that is a relic of colonialism, one aspect of which is the previously mentioned economic privileges of Westerners that enable the travelling that makes these statements possible (i.e., one roams and brings, while the other remains waiting to receive in a locality). Out of the same relationship emerges the perception of certain knowledge as transferable. Knowledge produced in the West has universal reach and can thereby be implemented outside of its point of origin. Thus, Western knowledge is distinguished from other sources of knowledge, which are tied to their locality.

Irremediably, one side's perception of itself as the source of knowledge and universally valuable reason seemingly replaces any desire for dialogue with a mere soliloquy, with the evoked subjects characterised by their socio-economic conditions rather than as agents of knowledge or even as agents of other types of knowledge. In the line of reasoning exemplified above, the students are reciprocated for their scientific contributions by being privileged spectators in an environment characterised by its social conditions and by being privy to the warmth experienced through contact with people who were not raised within the individualised societies of the Western world. These circumstances lead to soul searching by reinforcing what is important in life and acting as a remedy to life, which pertains to aspects beyond the individual satisfaction of commodities. 'When the Whites feel they have become too mechanised', wrote Frantz Fanon ([1952]2008, 108), 'they turn to the Coloreds and request a little human sustenance'. This observation demonstrates how the Other, in the informant's phrasing, is perceived as an object of comparison, as a physical reminder of a lost state. As the students note, although observing people in state of poverty may be mentally challenging, the viewer is rewarded in retrospect ('I think that it's good even though it's hard to see it'). Consequently, the embodied Other - here, Bolivians - remain as the Other and continue to serve a Western story of self-discovery ('makes you think of what's important in life'). Rather than being recognised for their own agency, they become reincorporated into a colonial discourse to provide what is lacking in the observer's self. Therefore, the meaning produced in the statements above is congruent with a logic in which the Other is not fully recognised as a subject. The focus is on what the counterparts have (or rather what they do not have). Paradoxically, their lack of material resources also becomes their greatest asset: by not having, they can be reified into an object with therapeutic merits for its Western observer. In these cases, their being is for the Western spectator.

\section{Conclusions}

In this paper, I attempted to explore the discourse on interculturality and problematise whether this discourse fundamentally reproduces the classificatory logic embedded in modernity that insists on differences (both external and internal) among cultures. As argued throughout the essay, a problematic tenet of interculturality becomes apparent in the statements made by the students in this study. By expressing anxiety in relation to multiculturalism, the concept being intimately linked to dichomatic thinking based on predetermined and essential cultural identities, the informants describe cultural barriers that need to be bridged by engaging in intercultural dialogue. Paradoxically, interculturality risks consolidating differences, constructing otherness through geo-political distinction and temporal spatiality, mobilising exclusively Western knowledge to grapple with intercultural encounters and transforming and shaping the imagined Other to move it closer to the level of modernity that the observer ostensibly represents. The analysis sketches a potentially core symptom of intercultural practice: the concurrent recognition and denial of differences, the stumbling into stereotypes and, in the words of Desai's novel $(2005,297)$, the desire for 'the genuine thing that just happened to be the cliché'. 
The students' descriptions of interculturality reveal that they are driven by desire, a longing for the remote and a yearning for the cultural Other. Other cultures are somewhere elsewhere, spaces onto which fantasies can be projected. These fantasies allow the subjects to construct themselves in a state of being that could be described as 'in between'. In Said's (1978) perspective on the colonial literature describing the Orient, the Other is portrayed as feminine, mysterious, backward, warm and unchanging, tropes that have all been displayed in the informants' statements. In contrast, the Western subject bears the scientific knowledge on how the Orient can develop and evolve and, for its own sake, learn Western ways of life. This discourse correlates with the students' perceived roles in encounters with other cultures. This act of assumed responsibility for problems encountered on a worldly scale risks disguising complicity in representations of the Other as an underdeveloped part of the same, which confirms the concept of history as linear. This representation situates others in a Western framework in which modernity is singular and the path to modernity follows a Western trajectory - at most, a change in content but not in terms from the detested multiculturalism. Consequently, what is overlooked is the possibility that local actors in non-Western parts of the world are claiming 'their modernity', which is delinked from Western imperatives and its reliance on capitalism to accomplish development. The students assert that humanity is one by assenting to modernity as one without accounting for the fact that humanity is also many just as interculturality, as it arose in Latin America, recognised modernity as many. Regardless of good intentions, seeking to improve the world according to a Western idea of what the world is may place the observer in the role of the coloniser.

On the one hand, this finding points to the importance of this type of study in exploring how coloniality may operate in the present. On the other hand, it should be remembered that, as Said (1993) concluded, the terms, visions and models that still structure our worldview are legacies from colonialism, in which explanations as to why things are the way they are hinges on the idea that the Western subject has never been equipped with tools other than Eurocentrism to deal with other cultures. Interculturality may well be an educational strategy that can help to build a common world in the age of globalisation, but it must be a world, to cite the Zapatistas, in which many worlds are possible.

\section{Acknowledgments}

I would like to express my gratitude to Andreas Fejes and Lisbeth Eriksson for valuable and helpful comments on previous drafts of this essay. Written while being a visiting scholar at Duke University, I am indebted to Walter Mignolo for his invitation and his insightful amendments to improve the text.

\section{References}

Azar, M. 1998. I Frankrikes namn: L'Algérie Française och den koloniala fetischismen. Divan 3-4: 38-52.

Banerjee, S., \& S. Linstead. 2001. Globalization, Multiculturalism and Other Fiction: Colonialism for the new Millennium? Organization 8, no. 4: 683-722.

Bhabha, H. K. 1994. The Location of Culture. London/New York: Routledge.

Bharucha, R. 1993. Theatre and the World: Performance and the Politics of Culture. London/New York: Routledge.

Brantefors, L. 1999. Mångkulturalismer - föreställningar om mångkulturalism och skola. Redaktionellt. Utbildning och Demokrati 8, no. 3: 1-10.

Camilleri, C. 1992. From multicultural to intercultural: How to move from one to the other. In Cultural diversity and the schools, ed. J. Lynch, C. Modgil and S. Modgil, 141-151. London: Falmer Press. 
Chauduhri, U. 1995. Beyond a 'Taxonomic Theater': Interculturalism after Postcolonialism and Globalization. The Drama Review 32, no. 1: 33-47.

Conrad, J. 1973. Heart of Darkness. Harlow: Penguin Books Ltd.

Council of Europe. 2008. Living together as equals in dignity (White Paper on Intercultural Dialogue). Strasbourg: CE.

Da Cunha, E. 1944. Rebellion in the backlands. Trans. Samuel Putnam. Chicago: University of Chicago Press.

Dahlén, T. 1997. Among the Interculturalistas: An Emergent Profession and its Packaging of Knowledge. Stockholm: Gotab.

Dahlstedt, M. 2009. Aktiveringens politik: Demokrati och medborgarskap för ett nytt Millennium. Malmö: Liber.

De los Reyes, P. 2001. Diversity and Differentiation. Stockholm: National Institute for Working Life.

Desai, K. 2005. The Inheritance of Loss. Little: Atlantic Monthly Press.

Dewey, P. 2008. Transnational Cultural Policymaking in the European Union. Journal of Arts Managment, Law, and Society 38, no. 2: 99-118.

Dussel, E. 1993. Eurocentrism and Modernity. Boundary 2 20, no. 3: 65-76.

European Commission. 2001. Communication from the Commission: Making a European Area of Lifelong Learning a Reality. Brussels: EC.

European Commission. 2007a. Communication from the Commission: A European Agenda for Culture in a Globalizing World. Brussels: EC.

European Cultural Parliament. 2007b. Sibu declaration on Intercultural Dialogue and Communicating the European Idea. Sibu: CE.

Fanon, F. 2008. Black Skin/White Masks. New York: Grove Press.

Hardt, M. and Negri, A. 2001. Empire. Cambridge: Mass: Harvard University Press.

Hardt, M. and Negri, A. 2003. Multitude. War and Democracy in the Age of Empire. New York: The Penguin Press.

James, M. 1999. Critical Intercultual Dialogue. Polity 31, no. 4: 587-607.

Jameson, F. 1993. On "Cultural Studies". Social Text 34: 17-52.

Kymlicka, W. 2003. Multicultural States and Intercultural Citizens, Theory and Research in Education 1, no. 2: 147-169.

Maldonado-Torres, N. 2004. The topology of being and the geopolitics of knowledge. City 8, no. 1: 29-56.

Mignolo, W. 1999. Local histories/global designs: coloniality, subaltern knowledges, and border thinking. Princeton: Princeton University Press.

Mignolo, W. 2000. The many faces of cosmopolis: border thinking and critical cosmopolitanism. Public Cult 12, no. 3: 721-748.

Mignolo, W. 2005. The idea of Latin America. Oxford: Blackwell Publishing.

Santos Riego, M. \& Nieto, S. 2000. Multicultural/intercultural teacher education in two contexts: lessons from the United States and Spain. Teaching and Teacher Education 16: 413-427.

Said, E. 1978. Orientalism. London: Vintage Books.

Said, E. 1993. Culture and Imperialism. London: Vintage Books.

Sutton, M. 2005. The globalization of multicultural education. Indiana Journal of Global Legal Studies, 12, no. 1: 97-108.

Trouillout M-R. 2002. North Atlantic Universals: Analytical Fictions, 1492-1945. The

South Atlantic Quarterly 101, no. 4: 839-858.

UNESCO 2006. Guidelines on Intercultural Education. Paris: UNESCO. 